\title{
TRAPEZOIDAL DRAINAGE BUCKET AND MPVS MOUNDING DEVICE PRODUCTIVITY AND MOUND QUALITY COMPARISON
}

\author{
Kristaps Makovskis ${ }^{1}$, Dagnija Lazdina ${ }^{1}$, Igors Gusarevs ${ }^{2}$, Germans Gusarevs ${ }^{2}$ \\ ${ }^{1}$ Latvian State Forest Research Institute "Silava", Latvia; ${ }^{2}$ Orvi Ltd., Latvia \\ kristaps.makovskis@silava.lv, dagnija.lazdina@silava.lv, orvi@inbox.lv, ggusarevs@gmail.com
}

\begin{abstract}
Forest site preparation before planting leads to growth condition improvement, better tree survival rate, and less agrotechnical care. The most popular and mainly used soil preparation methods in Latvia are disc trenching and mounding. In sites with high groundwater levels, the mounding soil preparation method in Latvia is used. The mounding soil preparation method is more expensive compared to disc trenching. To reduce mounding costs, working productivity is crucial. The study aims to compare the productivity and planting spot (mound) quality of two different mounding devices: trapezoidal drainage bucket and MPVS (forest mound device with a sprinkler). Trapezoidal drainage bucket could be used for 4 different soil preparation methods: classic mound, inverted topsoils mound, scratched mound, and working method, where together with drainage ditch-digging, mound banks were made. Assuming that it is necessary to prepare 2000 planting spots in a hectare, using the trapezoidal drainage bucket, the working productivity for using only the classic mounding soil preparation method is 8.3 hours, the inverse topsoil mound preparation method - 7.2 hours, and the scratched mound method 3.5 hours. When ditch-digging is done together with mound bank preparation - 13 hours. MPVS bucket productivity for preparing 2000 planting spots is 7.8 hours. From all mounds done with the MPVS bucket and measured for quality parameters, 92.4-94.3\% regardless of land type were good quality, while with the trapezoidal bucket, classic mounds (95\%) and bank mounds (100\%) showed good quality. Inverse topsoil mounds and scratched mounds did not meet the quality requirements, but could be used as extra planting spots in sites where classical mounds cannot be done or are unnecessary. Both mounding devices are suitable in Latvia conditions and could be successfully used for forest soil preparation in wet forest sites.
\end{abstract}

Keywords: trapezoidal bucket, mounds, MPVS bucket, soil preparation.

\section{Introduction}

In Latvia first studies on forest regeneration and soil preparation were started in Incukalns forest district in 1926, in more than 1000 ha, where various soil preparation methods were tested [1]. Further researches concluded that tree planting on elevations (mounds) has several advantages compared to furrows, as higher nutrient levels, plants heat up faster, grow faster, less weed competition, and total tree number planted on mounds could be lower on a hectare, compared to other soil preparation methods [2; 3]. In the Northern part of Europe, the most common forest soil preparation methods are disc trenching and mounding. In Sweden the most commonly used soil preparation method is disc trenching [4]. In Sweden, the soil inverting method is also practiced, which reduces soil surface disturbance compared with mounding and patch scarification [5]. In Finland, the most common forest soil preparation method is mounding, replacing disc trenching [6]. In Estonia, the most common forest soil preparation method is disc trenching [7]. Mounding is effective to enhance soil drainage increase soil temperature and favor seedling survival and early growth [5; 6]. Mounding creates less soil disturbance compared to disc trenching [9]. Soil inverting (mounding) before planting proved to improve seedling survival and increase growth rate [10],

A study done in Sweden, where site mounding was done with the Karl Oskar device, showed lower tree mortality from pine weevils [4]. Other studies in Sweden showed that 5 years after planting, control treatment showed greater mortality rates, compared to soil inversion and mounding sites [4]. Soil preparation productivity is highly affected by machines, for example, patch scarification (simplest soil preparation method) can be performed twice as quickly compared to the Karl Oskar mounding device [11]. On the other hand, mounds greatly reduced the time required for planting compared to other forest soil preparation methods [12]. In Finland, intermittent soil preparation in spots seems to be a less destructive method compared to other sol preparation methods [13].

Mainly used forest soil preparation methods in Latvia are disc trenching, mounding, and spot mounding. In wet soil sites the mounding soil preparation method in Latvia is used. Mounding is done with a standard excavator bucket or special mounding buckets and usual excavators as base machines. Special mounding buckets are designed to make mounding faster and more efficient. Mound quality could affect felling residues, stumps, and rocks on site. 
The mounding soil preparation method is more expensive compared to disc trenching, therefore, to reduce mounding costs, working productivity is crucial. Trials for special mounding device testings in Latvia were done in 2012, and working productivity with the MPV-600 device was 6.0 hours and for Karl-Oskar 5.6 hours when 1600 mounds were prepared [14].

In sites with high water levels, ditch-digging is done to remove excess water. In this case, a trapezoidal drainage bucket is used. Trapezoidal bucket together with ditch-digging could also be used in mound preparation. With trapezoidal buckets, several mounding methods could be used and combined in one site.

The study aims to compare the productivity and planting spot (mound) quality of two different mounding devices: trapezoidal drainage bucket and MPVS (forest mound device with a sprinkler).

\section{Materials and methods}

Study sites were located in the western part of Latvia. Mounding with the trapezoidal bucket was done in 4 locations and with MPVS in 5 locations. In all areas mounding was done using the same base machine Volvo EC140BLCM with a boom length of $7.8 \mathrm{~m}$, and the same machine operator did the work. Trapezoidal bucket width at the top $2150 \mathrm{~mm}$, width at the bottom $460 \mathrm{~mm}$, height $1100 \mathrm{~mm}$, depth $800 \mathrm{~mm}$, and weight $485 \mathrm{~kg}$. MPVS bucket width $600 \mathrm{~mm}$, length $964 \mathrm{~mm}$, height $756 \mathrm{~mm}$, and weight 586 kg, Fig. 1.
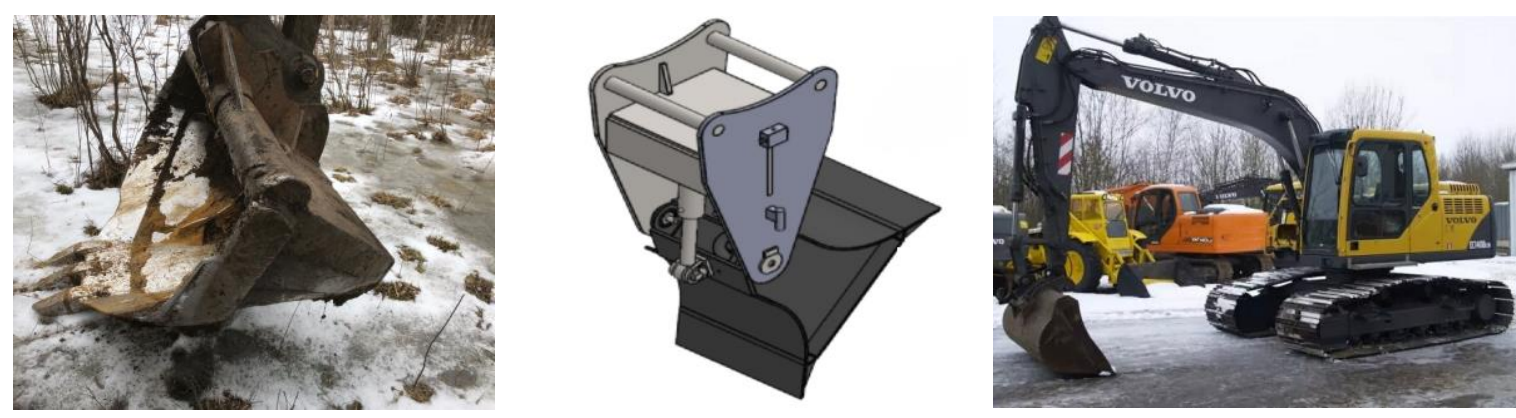

Fig. 1. Trapezoidal, MPVS buckets and base machine used in trials

Time studies for the trapezoidal bucket were carried out in the spring of 2018 and for MPVS in 2019. The time spent for making one mound was set as one working cycle. The time study was done using the SDI 1.2. timekeeping program (Haglof Sweden AB) installed on an Allegro CX field computer (Juniper Systems, USA). Several mounding activities within a working cycle were counted (Table 1).

Table 1

\section{Monitored activities in mounding time studies}

\begin{tabular}{|l|l|}
\hline \multicolumn{1}{|c|}{ Activity } & \multicolumn{1}{c|}{ Activity description } \\
\hline $\begin{array}{l}\text { Moving in } \\
\text { the site }\end{array}$ & $\begin{array}{l}\text { Base machine moving in the site between mounds. The start of operation is } \\
\text { considered the beginning of the crawler's movement in the site, and the end of the } \\
\text { operation is the cessation of the crawler's movement. }\end{array}$ \\
\hline $\begin{array}{l}\text { Boom } \\
\text { movement }\end{array}$ & $\begin{array}{l}\text { All activities related to the excavator boom movement, but not counted during } \\
\text { mounding spot preparation and mounding activities. }\end{array}$ \\
\hline $\begin{array}{l}\text { Site } \\
\text { cleaning }\end{array}$ & $\begin{array}{l}\text { Removal of twigs, felling residues, and roots before mound preparation. The start of } \\
\text { the operation is considered to be the moment when the bucket touches the branches } \\
\text { or cutting residues and starts to move them. The end of the operation is when the } \\
\text { bucket touches the soil, and the formation of the mound begins. }\end{array}$ \\
\hline $\begin{array}{l}\text { Mound } \\
\text { creation }\end{array}$ & $\begin{array}{l}\text { Mound creation activity. The start of the operation is when the bucket touches the } \\
\text { soil, and the formation of the mound begins. The end of the operation is when the } \\
\text { mound is pressed from the top, and the bucket is detached from the mound. }\end{array}$ \\
\hline $\begin{array}{l}\text { Other } \\
\text { activities }\end{array}$ & $\begin{array}{l}\text { Non-mounding activities during planting (talking on the phone, talking to each other, } \\
\text { small pauses, etc.). }\end{array}$ \\
\hline $\begin{array}{l}\text { Entering } \\
\text { and leaving } \\
\text { the site }\end{array}$ & $\begin{array}{l}\text { During accounting of the working time, it was found that these activities take a short } \\
\text { time in the specific areas. Therefore, they are not considered in the following } \\
\text { calculations. }\end{array}$ \\
\hline
\end{tabular}


With a trapezoidal bucket, 4 mound types were tested - scratched, inverted topsoil, classical mound, and working method, where together with drainage ditch-digging, mound banks were made. Mound bank preparation is done in wet sites, where together with ditch-digging or drainage system maintenance, mound banks could be made, or when together with mounding, ditch-digging or drainage system maintenance could be done. With the MPVS bucket, classical mounds were done.

In every site, where mounding was done, the mound length, width, and height were measured. With the trapezoidal bucket, the mound parameters were measured in 4 locations. The mound parameters for the MPVS bucket were measured in 1 location, where mounding was done on abandoned agricultural land, and in 4 locations, where mounding was done on forest land. According to the Latvian State Forest (LVM) quality standards, the mound length should be at least $60 \mathrm{~cm}$, width $50 \mathrm{~cm}$, and the height $15 \mathrm{~cm}$ [15].

Trapezoidal mounds were measured moving along the longest diagonal in the site, and all mounds with the step of 4 meters apart were measured, starting from the first mound in the site. In total 100 mounds in each preparation method were measured. For MPVS mounds, five evenly distributed circular sample plots were made in each site, with a radius of $2.82 \mathrm{~m}\left(\operatorname{area} 25 \mathrm{~m}^{2}\right)$.

\section{Results and discussion}

Mounding productivity depends on several factors, like the site configuration, soil type, logging residue density, stoniness, and the machine operator work experience [14]. Forest soil type could affect mounding productivity and quality. However, in practice, soil preparation is not done regardless of soil types, but according to necessity. Soil types could differ even within one area, therefore, it is necessary to collect a large amount of data, to include the soil type as a factor that affects productivity and quality. In this study, the forest type was not used as a factor in mounding device comparison.

When comparing one mound preparation time with the trapezoidal bucket, the fastest was the scratched mound preparation method - on average 6.3 seconds, for the inverted topsoil preparation method 13 seconds, for the classical mound method 15 seconds and when together with ditch-digging mound banks were done on average 23.4 seconds. With the MPVS bucket, one planting spot (mound) preparation took 14 seconds. Most time-consuming working operations were mound creations, on average $44-62 \%$, and boom movements on average $25-39 \%$ from the working cycle (one mound preparation), Fig.1.

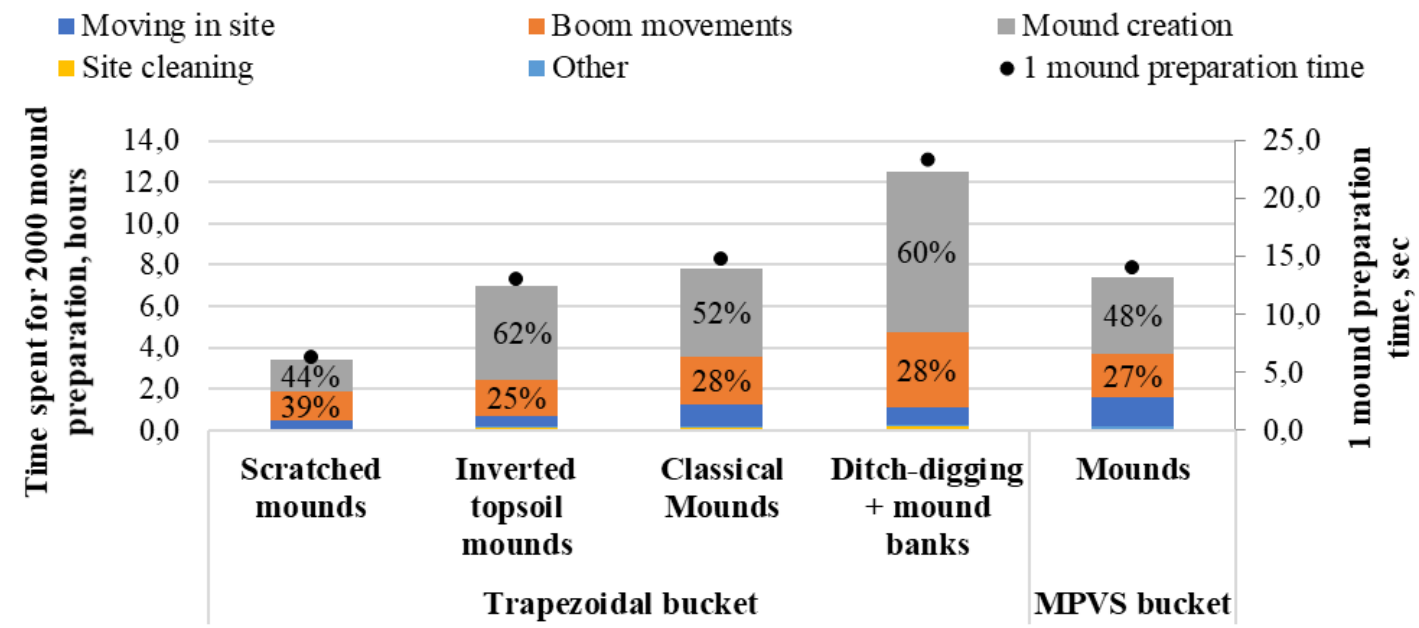

Fig. 1. Mounding productivity with trapezoidal and MPVS bucket

According to LSF requirements, the mound density in the site should be 1600-2800 mounds ha ${ }^{-1}$, depending on planted tree species and forest type [15]. Assuming that it is necessary to prepare 2000 planting spots in one hectare, using the trapezoidal bucket and doing ditch-digging + mound banks method it requires 13 hours, using only the classic mounding soil preparation method requires 8.3 hours, the inverted topsoil mounding method requires 7.2 hours, and the scratched mounding method requires 3.5 hours. With the MPVS bucket for 2000 mound preparation 7.8 hours are required. In 2012 trials with MPV-600 mounding device, 2000 mound preparation took 7.5 hours and with the Karl-Oskar 
mounding device 7.0 hours [14]. The increasing number of planting spots per hectare did not affect the survival or height growth of individual seedlings [5].

Different mound preparation methods could be combined in one site using a trapezoidal bucket, depending on circumstances, Table 2.

Table 2

Different trapezoidal bucket mound type combination and time spent for 2000 mound preparation

\begin{tabular}{|c|c|c|c|c|}
\hline \multicolumn{4}{|c|}{ Mounding type intensity } & \multirow{2}{*}{$\begin{array}{c}\text { Time spent for } 2000 \\
\text { planting spot preparation, } \\
\text { hours }\end{array}$} \\
\hline $\begin{array}{c}\text { Ditch digging + mound } \\
\text { banks }\end{array}$ & $\begin{array}{c}\text { Classical } \\
\text { mound }\end{array}$ & $\begin{array}{c}\text { Inverted } \\
\text { topsoil }\end{array}$ & $\begin{array}{l}\text { Scratched } \\
\text { mounds }\end{array}$ & \\
\hline $100 \%$ & - & - & - & 13 \\
\hline- & $100 \%$ & - & - & 8.30 \\
\hline $10 \%$ & $70 \%$ & $10 \%$ & $10 \%$ & 8.18 \\
\hline $30 \%$ & $50 \%$ & $10 \%$ & $10 \%$ & 9.13 \\
\hline $50 \%$ & $30 \%$ & $10 \%$ & $10 \%$ & 10.10 \\
\hline $70 \%$ & $10 \%$ & $10 \%$ & $10 \%$ & 11.00 \\
\hline
\end{tabular}

Inverted topsoil or scratched mound could be used in site corners or sides, where classical mounding is impossible, in areas with many felling residues, wide trailer paths, or many stumps and where it is hard to reach a minimum number of mounds per hectare. Inverted topsoils or scratched mounds could also be used on dry places in sites, where classical mounds are unnecessary. Different mound type combinations in one site can save time and therefore reduce the soil preparation costs.

The mound length in all sites, regardless of used mounding device and mound type, was over the quality threshold of $60 \mathrm{~cm}$. The minor exception was for some mounds on forest lands, where soil with the MPVS bucket was prepared. In this site, $1.6 \%$ of all measured mounds were under the threshold of $60 \mathrm{~cm}$, which is considered a minor derogation, Fig. 2.

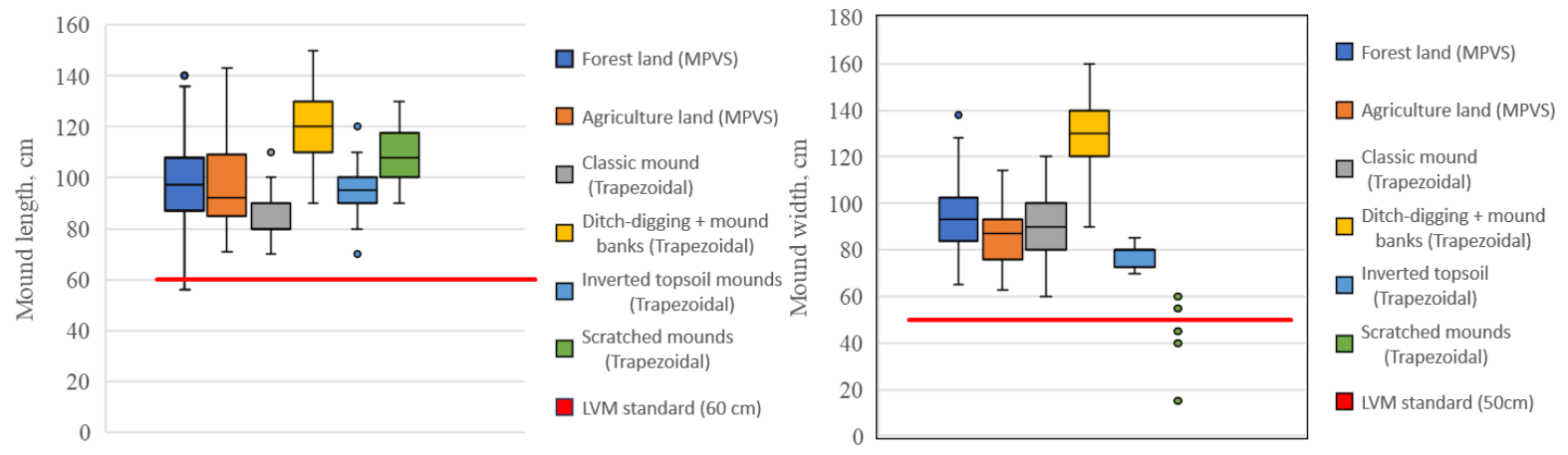

Fig. 2. Mound lengths and widths depending on the device used in mounding and their relevance to the Latvia State Forest standard for mound length

(*outliers in the graph are dots)

The mound width in all sites, except scratched mounds, was over the quality threshold of $50 \mathrm{~cm}$. The scratched mound width on mean was $50 \mathrm{~cm}$, with fluctuation of $10 \mathrm{~cm}$, and from all scratched mounds, $15 \%$ were under the threshold of $50 \mathrm{~cm}$ in width, Fig 2.

The mound height is one of the most critical parameters that define the mound quality. The height of the mound is essential to regulate the water level in the planting site. Sufficient mound height prevents mound from overgrowth with plants in the first year after planting, thereby improving tree growth conditions on site. The height is not measured for scratched mounds, because they are not over the top of the soil. According to the height standards, inverted topsoil mounds do not reach the standard of 15 cm height, Fig. 3. 


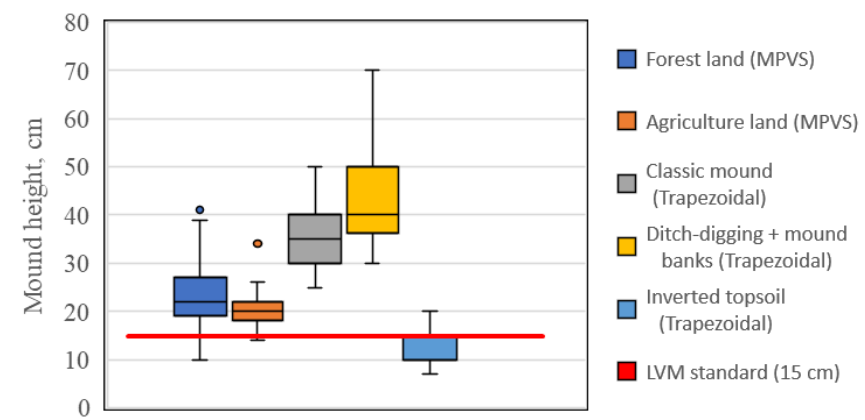

Fig. 3. Mound height depending on the device used in mounding and relevance to the Latvia State Forest standard for mound length (*outliers in the graph are dots)

To consider mounds as quality planting spots, all three parameters (length, width, height) must be fulfilled at the same time at the same mound, Table 3.

Mound mean parameters, standard deviation and quality

\begin{tabular}{|l|c|c|c|c|}
\hline \multicolumn{1}{|c|}{ Mound type } & Length, cm & Width, cm & $\begin{array}{c}\text { Height, } \\
\text { cm }\end{array}$ & $\begin{array}{c}\text { Mound } \\
\text { quality, \% }\end{array}$ \\
\hline Forest land (MPVS) & $97.2 \pm 16.6$ & $93.6 \pm 13$ & $23 \pm 6$ & 92.4 \\
\hline Agriculture land (MPVS) & $95.78 \pm 15$ & $85.6 \pm 10.7$ & $20.2 \pm 4$ & 94.3 \\
\hline Classic mound (trapezoidal) & $84.4 \pm 9.8$ & $90 \pm 14.1$ & $34.7 \pm 5.4$ & 95.0 \\
\hline $\begin{array}{l}\text { Ditch digging + mound banks } \\
\text { (trapezoidal) }\end{array}$ & $119.3 \pm 14.5$ & $127 \pm 15.7$ & $45.9 \pm 4.5$ & 100.0 \\
\hline Inverted topsoil (trapezoidal) & $95 \pm 11.4$ & $77.8 \pm 4.69$ & $13.1 \pm 4.2$ & 60.0 \\
\hline Scratched mounds (trapezoidal) & $108.2 \pm 11.23$ & $48.3 \pm 8.6$ & - & - \\
\hline
\end{tabular}

For all mounding types, the length criteria of $60 \mathrm{~cm}$ were fulfilled, while the width criteria of $50 \mathrm{~cm}$ were unfulfilled only with the scratched mound preparation method. On average, the mound height was insufficient with inverted topsail and scratched mound preparation methods. In study where the UOT M22 rotating mounder was used, 50.6\% of planting spots meet the quality requirements [16].

\section{Conclusions}

1. With the MPVS bucket, one planting spot (mound) preparation took 14 seconds. With the trapezoidal bucket, using the classic mound method one planting spot preparation took 15 seconds, mound banks together with ditch-digging took 23.4 seconds, the inverted topsoil method took 13 seconds and the scratched mound method took 6.3 seconds.

2. From all mounds that were done with the MPVS bucket and measured for quality parameters, 92.4-94.3\% regardless of the land type were good quality, which means that the mound length, width, and height were sufficient. For mounds done with the trapezoidal bucket, only classic mounds (95\%) and bank mounds (100\%) showed good quality, but inverted topsoil and scratched mounds did not meet the quality standards. These mound types could be used as extra planting spots in sites where classical mounds cannot be done or are unnecessary.

\section{Acknowledgments}

This study was part of The European Agricultural Fund for Rural Development (EAFRD) for the years 2014-2020 of the Latvian Rural Development Programme (RDP) project: "Development of a multi-functional mounding device for forest restoration in stands with fertile and humid soils", project No. 18-00-A01620-0000352.

\section{References}

[1] Eihe V. Virsāju apmežošanas jautājums Inčukalna virsmežniecībā (Heathland afforestation in Incukalna forest district). Mežsaimniecības rakstu krājums, vol. XVII, 1939, pp. 3-19. (In Latvian) 
[2] Bušs K. Labs piemērs meža kultūru lietā (A good example in the case of forest crops). Meža dzīve, vol. 86, 1932, pp. 3170-3172. (In Latvian)

[3] Katkevics K., Lukasunas I. Augsnes sagatavošanas veida ietekme uz baltalkšņu stādījumu augšanu (Influence of soil preparation type on the growth of grey alder plantations). Jaunākais mežsaimniecībā, vol. 28, 1986, pp. 59-63. (In Latvian)

[4] Wallertz K., Björklund N., Hjelm K., Petersson M., Sundblad J.G. Comparison of different site preparation techniques: quality of planting spots, seedling growth and pine weevil damage. New For., vol. 49, 2018, pp. 705-722.

[5] Hallsby G., Örlander G. A comparison of mounding and inverting to establish Norway spruce on podzolic soils in Sweden. Forestry, vol. 77(2), 2004, pp. 107-117.

[6] Laine T., Kärhä K., Hynönen A. A survey of the Finnish mechanized tree-planting industry in 2013 and its success factors. Silva Fenn., vol. 50(2), 2016, pp. 1-14.

[7] Kalev J., Metslaid M., Uri V. Afforestation and Land Use Dynamics in the Baltic States. Restoration of Boreal and Temperate Forests. CRC Press, 2015, pp. 202-215.

[8] Mc Carthy R., Rytter L., Hjelm K. Effects of soil preparation methods and plant types on the establishment of poplars on forest land. Ann. For. Sci., vol. 74(2), 2017.

[9] Buitrago M., Paquette A., Thiffault N., Bélanger N., Messier C. Early performance of planted hybrid larch: effects of mechanical site preparation and planting depth. New For., vol. 46(3), 2015, pp. 319-337.

[10] Johansson K., Nilsson U., Örlander G. A comparison of long-term effects of scarification methods on the establishment of Norway spruce. Forestry, vol. 86(1), 2013, pp. 91-98.

[11]Ersson B.T., Jundén L., Lindh E.M., Bergsten U. Simulated productivity of conceptual, multiheaded tree planting devices. Int. J. For. Eng., vol. 25(3), 2014, pp. 201-213.

[12] Löf M., Dey D.C., Navarro R.M., Jacobs D.F. Mechanical site preparation for forest restoration. New For., vol. 43(5), 2012, pp. 825-848.

[13] Rabinowitsch-Jokinen R., Vanha-Majamaa I. Immediate effects of logging, mounding and removal of logging residues and stumps on coarse woody debris in managed boreal Norway spruce stands. Silva Fenn., vol. 44(1), 2010, pp. 51-62.

[14] Lazdina D. Augsnes sagatavošanas veida izvēles slapjaiņos, kūdreņos un ārenosos teorētiskais pamatojums, darbu ražīguma un pašizmaksas izpēte (Theoretical substantiation of the choice of soil preparation type in wetlands, peat and arable land, research of work productivity and cost). [online] [23.03.2021]. Available at: https://www.lvm.lv/petijumi-un-publikacijas/augsnes-sagatavosanasveida-izveles-slapjainos-kudrenos-un-arenos-teoretiskais-pamatojums-darbu-raziguma-unpasizmaksas-izpete. (In Latvian).

[15] Kvalitātes prasības augsnes gatavošanas darbu izpildei, veidojot pacilas (Quality requirements for soil preparation with mounding). [online] [17.03.2021]. Available at: https://www.lvm.lv/images/lvm/kvalitates_prasiba_augsnes_gatavosanai_ar_pacilu_metodi_2019. 05.17.pdf (In Latvian).

[16] Dumins K, Stals T, Lazdina D. Quality assesment of spots mounds. Engineering for rural development, vol. 325, 2020, pp. 1444-1449. 